\title{
PENINGKATAN PENGETAHUAN DAN KESADARAN REMAJA PUTRI DALAM MELAKUKAN PEMERIKSAAN PAYUDARA SENDIRI (SADARI) DETEKSI DINI KANKER PAYUDARA PADA SISWI KELAS X DI SMK NEGERI 2 KARAWANG TAHUN 2020
}

\author{
Rohani Siregar ${ }^{1)}$ \\ 1)Jurusan Sarjana Kebidanan, Institut Medika Drg Suherman, Cikarang, Jawa Barat, Indonesia \\ Corresponding author: Rohani Siregar \\ E-mail : rohanisiregar81@gmail.com
}

Diterima 01 Maret 2021, Direvisi 25 Maret 2021, Disetujui 26 Maret 2021

\begin{abstract}
ABSTRAK
SADARI merupakan salah satu tindakan deteksi dini kanker payudara yang dapat dilakukan oleh perempuan sejak usia remaja sampai usia premenopause. Saat ini banyak ditemukan remaja putri yang berusia empat belas tahun yang menderita tumor payudara, bila tidak terdeteksi lebih awal, maka tumor akan berubah menjadi kanker. Tujuan dari pengabdian masyarakat ini adalah untuk mencegah terjadi nya kanker payudara pada remaja putri di SMK Negeri 2 Karawang. Hasil wawancara dari beberapa siswi mereka tidak mengetahui sama sekali apa itu SADARI bahkan tidak pernah melakukan nya. Manfaat dilakukan penyuluhan tentang Pemeriksaan Payudara Sendiri (SADARI) untuk deteksi dini kanker payudara pada usia remaja dengan menggunakan metode penyuluhan Pre dan Post dalam melakukan praktik SADARI, Hasil pengabdian masyarakat ini remaja putri dapat melakukan pemeriksaan payudara sendiri (SADARI) sesuai dengan Langkah-langkah SADARI yang sudah di sosialisaikan secara virtual. Dan ingin melakukan secara rutin pada hari ke 5-10 menstruasi guna untuk mencegah terjadinya kanker payudara sedini mungkin.
\end{abstract}

Kata kunci : SADARI; kanker payudara; remaja putri

\begin{abstract}
Breast Self Examination ( SADARI) is one of the act of early detection breast cancer that can be done by women since early adolescence to the age of premenopause. Now many found adolescent girls aged fourteen years who suffered a breast tumor, if not detected early, so tumor will be turned into cancer, The purpose of devotion these communities is to prevent from happening his of breast cancer in adolescent girls in state vocational schools 2. The results of the interviews of several of them do not know at all what is that realized never even doing it .Benefits done counseling on audit of Breast self Examination (SADARI) to early detection of breast cancer in early adolescence. By using the method counseling pre and post in doing practices realized, The results of this community service young women can perform breast self-examination (BSE) in accordance with the BSE steps that have been socialized virtually. And want to do it regularly on days $5-10$ of menstruation in order to prevent breast cancer as early as possible.
\end{abstract}

Keywords: SADARI; breast cancer; adolescent girls

\section{PENDAHULUAN}

Kanker payudara merupakan tumor ganas yang menyerang jaringan sel-sel payudara. Masalah paling besar yang menyebabkan kematian pada wanita diseluruh dunia adalah kanker payudara, di negara berkembang menunjukkan bahwa penyakit kanker payudara mencapai presentasi kasus tertinggi, yaitu kurang lebih $43 \%$ kasus, dan terdapat $12,9 \%$ terdapat kasus kematian.

Data Global Cancer Observatory dari

World Health Organization (WHO) menunjukkan bahwa kasus kanker yang tertinggi di Indonesia adalah kanker payudara, yaitu terdapat 58.256 kasus atau $16,7 \%$ dari total 348.809 kasus kanker. Pada tahun 2019 ini di prediksikan hamper 9 juta orang meninggal diseluruh dunia akibat kanker dan akan terus meningkat hingga 13 juta orang pertahun di 2030. (Rivanica \& Dayanti, 2020)

Kementerian Kesehatan (Kemenkes) menyatakan, angka kanker payudara di Indonesia mencapai 42,1 orang per 100 ribu penduduk. Rata-rata kematian akibat kanker ini mencapai 17 orang per 100 ribu penduduk. Sementara itu, angka kanker serviks di Indonesia mencapai 23,4 orang per 100 ribu penduduk. Rata-rata kematian akibat kanker 
serviks mencapai 13,9 orang per 100 ribu penduduk (RI, 2019)

Hasil Riskesdas 2013, menunjukkan bahwa prevalensi kanker leher Rahim sebesar $0.8 \%$ dan kanker payudara sebesar $0.5 \%$, Adapun di Jawa Barat pada tahun 2013 sebanyak $0.7 \%$ untuk kanker leher Rahim dan $0.3 \%$ untuk kejadian kanker payudara. (dinkes provinsi jabar, 2017)

Berdasarkan data Sistem Informasi Rumah Sakit (SIRS) tahun 2010, kasus rawat inap kanker payudara terdapat 12.014 kasus $(28,7 \%)$. Diikuti dengan kasus kanker Rahim sebanyak 5.349 kasus (12,8\%). (Kementerian Kesehatan RI, 2016)

Di Kabupaten Karawang dalam 5 tahun terakhir yang di curigai kanker payudara sebanyak 71 kasus.(Karawang, n.d.)

Kanker payudara umumnya di alami oleh perempuan, dan menjadi jenis kanker yang menakutkan bagi perempuan di seluruh dunia termasuk Indonesia. Kurangnya Kesadaran perempuan untuk memeriksakan kondisi payudara nya. Sehingga banyak perempuan mengetahui bahwa dia telah memasuki kanker payudara di stadium lanjut. Jika kasus kanker dapat diketahui sedini mungkin, maka akan memiliki peluang lebih untuk mendapatkan penanganan lebih baik dan akan memberikan angka kesembuhan sehingga dapat meningkatkan harapan hidup (Sari et al., 2020)

SADARI merupakan suatu metode sederhana yang dapat dilakukan untuk deteksi dini kanker payudara, SADARI itu mudah di lakukan, tidak mahal, tidak nyeri, tidak berbahaya dan nyaman dilakukan. Namun hanya sekitar dua pertiga wanita mau mempraktikkan nya sekali setahun, dan sepertiga mau mempraktikkan nya tiap bulan, dan sekitar setengahnya dapat melakukan dengan benar. Hal ini disebabkan kurang nya informasi dan pengetahuan remaja putri tentang SADARI. (Wardhani et al., 2017)

Pemeriksaan payudara sendiri (SADARI) dapat dimulai sejak wanita sudah masuk pada masa puberitas, Hal ini perlu dilakukan agar dapat mengetahui sedini mungkin kelainan yang terjadi pada payudara. sehingga penanganan lebih cepat dan tepat. (Setyawan et al., 2019)

SADARI lebih efektif dilakukan pada wanita usia yang masih muda dan usia produktif 15-49 tahun. Wanita dengan usia tersebut beresiko terkena tumpr ataupun kanker payudara, Namun sampai saat ini kesadaran wanita masih sangat rendah terhadap praktik SADARI, yaitu hanya sekitar 25\%-30\%. Rendahnya kesadaran wanita disebabkan kurangnya edukasi dan pengetahuan wanita tentang pentingnya melakukan praktik SADARI. (Sari et al., 2020)

Berdasarkan hasil wawancara dari beberapa Remaja putri/siswi kelas X SMK Negeri 2 Karawang, bahwa mereka tidak mengetahui tentang pemeriksaan payudara sendiri (SADARI) dan belum pernah sama sekali melakukan kan nya, dan belum pernah mendapatkan penyuluhan dan edukasi dari tenaga Kesehatan tentang pemeriksaan payudara sendiri (SADARI) deteksi dini kanker payudara. Dan belum ada juga kurikulum tentang Kesehatan reproduksi remaja di SMK Negeri 2 Karawang

Adapun Tujuan dari pengabdian masyarakat ini adalah untuk meningkatkan pengetahuan dan kesadaran remaja putri terhadap pemeriksaan payudara sendiri (SADARI) Deteksi dini kanker payudara. Dan dapat melakukan SADARI secara rutin 1 bulan sekali yaitu pada hari ke 7-10 menstruasi.

\section{METODE}

Kegiatan pengabdian masyarakat dilaksanakan pada masa pandemik covid-19, secara virtual, yang diikuti oleh Remaja Putri kelas X SMK Negeri 2 Karawang sebanyak 50 orang peserta, yang mana kegiatan ini dilaksanakan di SMK Negeri 2 Karawang. metode penyuluhan Pre dan Post SADARI, dengan 2 sesi pertemuan, Adapun sesi pertama yaitu pada tanggal 02 Oktober 2020, dengan cara memberikan pre test sebanyak 10 soal dengan jawaban benar dan salah, dan matrikulasi mengenai kanker payudara dan pentingnya melakukan pemeriksaan payudara sendiri (SADARI), dan edukasi mengenai pencegahan kanker payudara. Pada hari ke-2 yaitu tanggal 09 Oktober 2020. memberikan materi tentang kanker payudara (Metode SADARI, manfaat SADARI dan waktu yang tepat melakukannya. Kemudian demonstrasi stimulasi cara melakukan Praktik SADARI dengan Langkah-langkah yang benar dan tepat. Di akhir kegiatan diberikan post test dengan soal yang sama, untuk mengevaluasi adanya perubahan tingkat pengetahuan siswi tentang metode SADARI.

\section{HASIL DAN PEMBAHASAN}

Kegiatan pengabdian masyarakat ini dilakukan dengan menggunakan zoom yang di ikuti oleh remaja putri kelas X SMK Negeri 2 Karawang, yang mana dilakukan dengan dua sesi yaitu pre dan post, sesi pertama memberikan Pendidikan Kesehatan mengenai pemeriksaan payudara sendiri (SADARI) deteksi dini kanker payudara dan Langkah-langkah SADARI . 


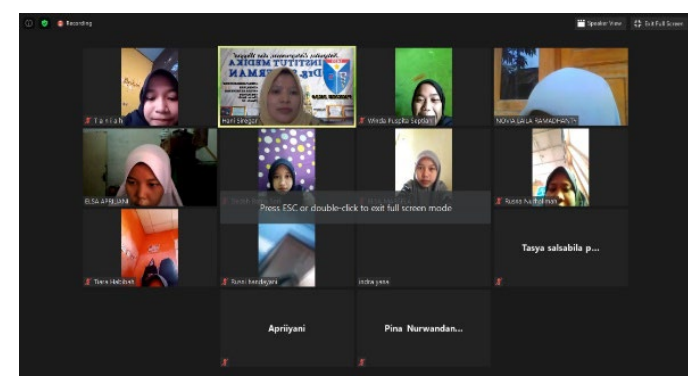

Gambar 1. Sosialisasi kanker payudara Kegiatan pemaparan materi kepada remaja putri SMK Negeri 2 Karawang tentang kanker payudara dan pemeriksaan payudara sendiri.

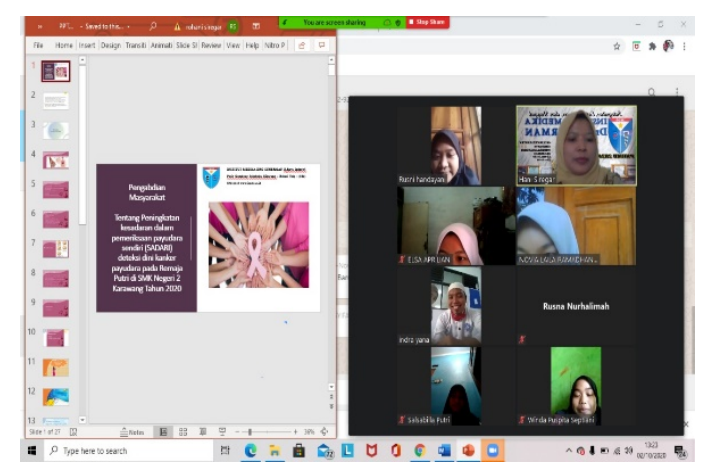

Gambar 2. Sosialisasi Langkah-langkah pemeriksaan payudara sendiri.

Kegiatan pengabdian masyarakat pada sesi ke 2 mengenai SADARI, yang mana remaja putri SMK Negeri 2 Karawang mencoba melakukan pemeriksaan payudara sendiri sesuai Langkah-langkah SADARI, setelah mengikuti sosialisasi pada sesi pertama.

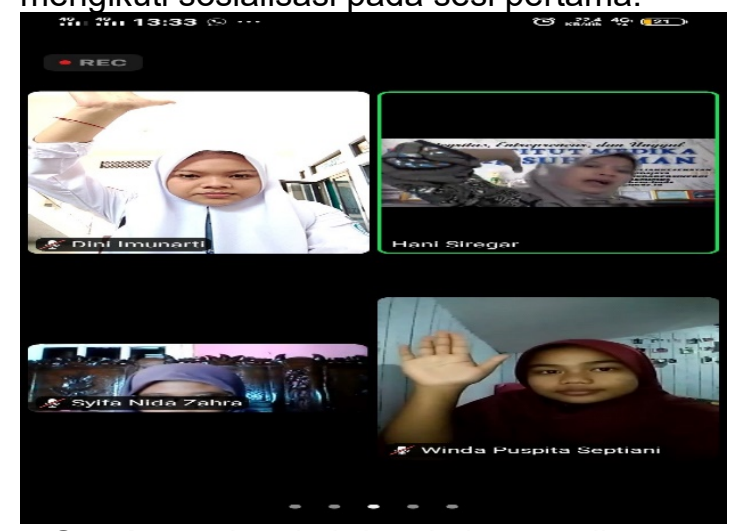

Gambar 3. langkah-langkah pemeriksaan payudara sendiri

Evaluasi pada remaja putri SMK Negeri 2 Karawang, yang mana mereka dapat melakukan praktik pemeriksaan payudara sendiri, dan akan rutin melakukannya pada hari ke 7-10 menstruasi, untuk mendeteksi sedini mungkin kanker payudara.

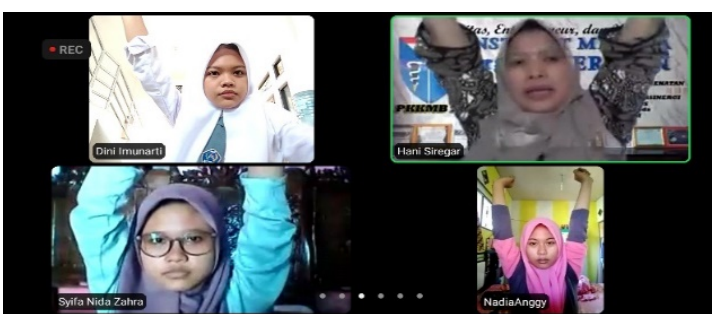

Gambar 4. Remaja putri dapat melakukan praktik SADARI dengan benar

\section{SIMPULAN DAN SARAN}

masyarakat tentang Peningkatan Pengetahuan dan Kesadaran Remaja Putri Dalam Melakukan Pemeriksaan Payudara Sendiri (SADARI) Deteksi Dini Kanker Payudara berjalan dengan lancar, Dan mendapatkan respon yang baik dari remaja Putri / Siswi, Adapun hasil evaluasi pada sesi ke 2 yang mana remaja putri/siswi dapat melakukan langkah-langkah SADARI.

Dengan adanya Penyuluhan tentang SADARI, Remaja putri SMKN 2 mengharapkan diadakannya kegiatan Penyuluhan Kembali terkait dengan Kesehatan Reproduksi.

Saran dari pelaksana antara lain Setelah mendapatkan penyuluhan ini, remaja putri rutin melakukan praktik pemeriksaan payudara sendiri (SADARI) dengan benar sesuai dengan Langkah-langkah SADARI, dilakukan sebulan sekali yaitu pada hari ke- 7 - 10 menstruasi, untuk deteksi dini kanker payudara.

\section{UCAPAN TERIMAKASIH}

Kegiatan ini terlaksana dengan dibiayai oleh Institusi yaitu dana hibah internal yang tertuang dalam surat kontrak Pkm : No 078/V/LPPM-IMDS/III/2020, oleh karena itu ucapan terimakasih disampaikan kepada pihak-pihak terkait yang ikut andil dan membantu dalam pelaksanaan kegiatan pengabdian masyarakat ini sampai tersusunnya manuskrip jurnal yang akan dipublikasikan.

\section{DAFTAR RUJUKAN}

Dinkes provinsi jabar. (2017). Kegiatan deteksi dini terhadap kanker serviks dan kanker payudara.

Karawang, D. kab. (n.d.). data kasus kanker payudara. 2019.

Kementerian Kesehatan RI. (2016). Bulan Peduli Kanker Payudara. http://www.depkes.go.id/resources/do wnload/pusdatin/infodatin/InfoDatin
Bulan Peduli Kanker Payudara_2016.pdf

RI, K. (2019). hari kanker sedunia 2019. 
Rivanica, R., \& Dayanti, K. P. (2020). Tingkat pengetahuan dan sikap remaja putri dengan perilaku periksa payudara sendiri (SADARI). Jurnal 'Aisyiyah Medika, 5(2), 244-252.

Sari, P., Sayuti, S., Ridwan, M., Rekiaddin, L. O., \& Anisa, A. (2020). Hubungan antara Pengetahuan dan Dukungan Tenaga Kesehatan dengan Perilaku Pemeriksaan Payudara Sendiri (SADARI) pada Wanita Pasangan Usia Subur (PUS). Perilaku Dan Promosi Kesehatan: Indonesian Journal of Health Promotion and Behavior, 2(2), 31. https://doi.org/10.47034/ppk.v2i2.4132

Setyawan, F. E. B., Rahmawati, S., \& Fatmawati, N. (2019). Analisis Faktor Perilaku terhadap Deteksi Dini Tumor Payudara dengan Tindakan SADARI pada Siswi SMA di Kota Malang. HerbMedicine Journal, 2(2), 79. https://doi.org/10.30595/hmj.v2i2.5629

Wardhani, A. D., Saraswati, L. D., Adi, M. S., Peminatan, M., Kesehatan, E., \& Semarang, F. K. M. U. (2017). Gambaran Pengetahuan Remaja Putri Tentang Sadari Dan Praktik Pemeriksaan Payudara Sendiri. Jurnal Kesehatan Masyarakat (e-Journal), 5(1), 180-185. 